\title{
Pengembangan Buku Pengayaan "Kajian Fisis Peristiwa Angin Puting Beliung” untuk Siswa SMA
}

\author{
Desnita $^{\text {a) }}$, Noviana Fadilah ${ }^{\text {b) }}$, Esmar Budi \\ Program Studi Pendidikan Fisika FMIPA UNJ, Jl. Pemuda No 10, Jakarta 13220 \\ Email: a)desywaznadil@gmail.com, b) novi.dilah211@gmail.com
}

\begin{abstract}
This research is aimed to develop knowledge enrichment book about tornado as a physics learning resource, especially to Bassed Competence 3.7 Class XI, namely Applying the principle of fluid dynamics in technology. The method applied in this research is the Development Research referring to the Dick and Carey model. Steps that was done are survey in eight high school, two well-known bookstore in Jakarta, online bookstore, and Pusat Kurikulum dan Perbukuan (Puskurbuk). The survey results show there is knowledge enrichment book is presented with more focus on the disaster that is less scientific and less deep because only limited discuss section. Referring to the results of the survey and quality standards enrichment books, knowledge enrichment book is written by discuss mainly the physical quantities of gas flow especially pressure gradient, the events and the physical concept of tornado, to disaster mitigation. Based on results of the readability test to high school students is obtained a mean score of materials component is $92,5 \%, 88,5 \%$ for presentation, $84,17 \%$ for language, and $85,62 \%$ for graphics. Score $87,5 \%$ stated that the material in the book is easy to understand and $82,5 \%$ stated that the presentation materials may be motivated to dig up more information. Based on results of readability test, thin book obtaine excellent overall interpretation. Based on the results of the feasibility test, gets an average score of 81,05, showing knowledge enrichment book "Kajian Fisis Peristiwa Angin Puting Beliung" decent with a good rating.
\end{abstract}

Keywords: knowledge enrichment book, tornado, pressure, air flow

\begin{abstract}
Abstrak
Penelitian ini bertujuan untuk mengembangkan buku pengayaan pengetahuan angin puting beliung sebagai sumber belajar fisika terutama untuk Kompetensi Dasar (KD) 3.7 Kelas XI, yaitu Menerapkan prinsip fluida dinamik dalam teknologi. Metode yang diterapkan yaitu Penelitian Pengembangan yang mengacu pendapat Dick dan Carey. Langkah yang sudah dilakukan yaitu survei di delapan SMA, dua toko buku terkenal di Jakarta, toko buku online, dan Pusat Kurikulum dan Perbukuan (Puskurbuk). Hasil survei menunjukkan sajian buku pengayaan terkait angin puting beliung yang ada lebih fokus pada bencana sehingga kurang ilmiah dan kurang mendalam karena hanya sebatas dalam satu subbab. Mengacu pada hasil survei dan standar kualitas buku pengayaan, ditulis buku pengayaan pengetahuan yang membahas besaran fisis aliran gas terutama gradien tekanan, peristiwa dan konsep fisis terjadinya angin puting beliung, hingga mitigasi bencana. Berdasarkan hasil uji keterbacaan kepada siswa SMA diperoleh rerata skor komponen materi $92,5 \%$, penyajian $88,5 \%$, bahasa $84,17 \%$, dan grafika $85,62 \%$. Skor $87,5 \%$ menyatakan materi pada buku mudah dipahami dan $82,5 \%$ menyatakan penyajian materi dapat memotivasi untuk menggali informasi lebih lanjut.
\end{abstract}


Dari hasil uji keterbacaan, buku ini memperoleh interpretasi keseluruhan sangat baik. Berdasarkan hasil uji kelayakan diperoleh rata-rata skor 81,05, menunjukkan buku pengayaan pengetahuan "Kajian Fisis Peristiwa Angin Puting Beliung" layak dengan predikat baik.

Kata-kata kunci: buku pengayaan pengetahuan, angin puting beliung, tekanan, aliran gas

\section{PENDAHULUAN}

Di dunia terjadi pemanasan global (global warming) yang berakibat banyak terhadap keadaan bumi ini, salah satunya cuaca ekstrim. Di indonesia sendiri, cuaca ekstrim dapat mengakibatkan berbagai becana, seperti banjir, kekeringan, dan angin puting beliung. Suhu yang tinggi merupakan salah satu penyebab terjadinya angin puting beliung (Nurjani 2013).

Angin puting beliung terjadi pada daerah yang memiliki gradien temperatur yang besar (Siswanto 2012). Gradien temperatur berpengaruh kepada gradien tekanan dan juga kecepatan angin. Angin berhembus dari daerah bertemperatur rendah menuju daerah bertemperatur tinggi atau dari daerah bertekanan tinggi menuju daerah bertekanan rendah (Primus 2015). Dimana semakin besar gradien temperatur dan gradien tekanan akan semakin besar pula kecepatan angin,

Menurut Sudibyakto dan Daryono (2008) ada tiga fase terjadinya angin puting beliung, yaitu:

1. Fase tumbuh: Ketika suatu daerah memiliki gradien temperatur vertikal di atas $\left(-0,8^{\circ} \mathrm{C}\right) / 100$ meter, membuat udara di sekitar terasa panas sehingga akan menghisap banyak uap air dan munculah arus udara naik yang kuat dan membentuk awan konvektif (Chapter 9: The temperature gradient).

2. Fase dewasa/masak: gradien tekanan horizontal yang besar akan menyebabkan angin dari daerah sekitar menuju daerah bertekanan rendah dengan kecepatan tinggi sehingga ketika massa udara berkecepatan tinggi yang bertentangan bertemu akan menyebabkan arus-arus udara ini membentuk pusaran yang juga dipengaruhi oleh gaya Coriolis (Gomduri 2016).

3. Fase punah: tidak ada lagi udara yang naik dan udara yang turun perlahan meluas ke seluruh awan dan kemudian melemah sehingga angin puting beliung hilang (Sudibyakto \& Daryono 2008).

Angin puting beliung berpotensi besar terjadi di indonesia. Bencana ini telah mengakibatkan banyak kerugian terutama kerusakan bangunan. Untuk meminimalisir kerugian terjadinya bencana, masyarakat perlu mengetahui info mengenai peristiwa angin puting beliunbencana ini.

Tidak hanya info umum untuk masyarakat, peristiwa angin puting beliung dapat dijadikan bahan pengayaan dalam proses pembelajaran khususnya dalam pembelajaran fisika. Hal ini dikarenakan peristiwa angin puting beliung terkait dengan konsep fisika seperti konveksi, gradien tekanan, gaya Coriolis,dan khususnya dalam materi fluida dinamis pada persmaan Bernoulli dan aliran vortex.

Buku pengayaan diartikan sebagai buku yang memuat materi yang dapat memperkaya dan meningkatkan penguasaan ilmu pengetahuan, teknologi, dan seni (ipteks) serta keterampilan dalam membentuk kepribadian peserta didik, pendidik, pengelola pendidikan, dan masyarakat lainnya (Pedoman Penilaian Buku Nonteks Pelajaran tahun 2014). Buku pengayaan berisi bahasan tertentu yang ada dalam kurikulum secara lebih luas dan/atau lebih dalam. Buku ini tidak disusun sepenuhnya berdasarkan kurikulum baik dari tujuan, materi pokok, dan metode penyajian. Buku ini tidak wajib dipakai oleh peserta didik tetapi berguna bagi peserta didik yang mengalami kesulitan memahami pokok bahasan tertentu dalam buku teks pelajaran pokok (Sitepu 2012).

Buku pengayaan dikelompokkan menjadi (1) buku pengayaan pengetahuan, (2) buku pengayaan keterampilan, dan (3) buku pengayaan kepribadian (Pedoman Penilaian Buku Nonteks Pelajaran tahun 2014). Buku pengayaan pengetahuan merupakan buku-buku yang dapat mengembangkan pengetahuan (knowledge development) peserta didik, menambahkan ilmu pengetahuan yang tidak diperoleh dari buku teks pelajaran dikarenakan informasi pengetahuan pada buku pengayaan pengetahuan lebih luas atau mendalam (Pedoman Penilaian Buku Nonteks Pelajaran tahun 2014). Sehingga setelah membaca buku pengetahuan pengayaan, diharapkan dapat bermanfaat memperkaya wawasan, pemahaman dan penalaran pembaca sasaran.

Buku pengayaan pengetahuan memiliki karakteristik tersendiri yang berbeda dengan buku pengayaan lainnya. Karakteristik buku pengayaan pengetahuan, yaitu, (1) menyajikan materi yang bersifat kenyataan, (2) mengembangkan materi bacaan yang bertumpu pada ilmu, dan (3) mengembangkan berbagai pengetahuan seperti pengetahuan faktual, pengetahuan konseptual, 
pengetahuan prosedural, dan pengetahuan metakognitif (Pedoman Penilaian Buku Nonteks Pelajaran tahun 2014).

Buku pengayaan pengetahuan tidak hanya bermanfaat masyarakat umum dan peserta didik. Tetapi sebagai calon guru fisika SMA penulis juga perlu membekali diri dengan pengalaman dan pengetahuan untuk mengembangkan materi pengayaan dalam bidang fisika.

\section{METODE PENELITIAN}

Metode penelitian yang digunakan adalah penelitian pengembangan yang mengacu dari teori Dick and Carey (2009) dengan tahapan sebagai berikut.

1. Mengidentifikasi kebutuhan instruksional dan menulis tujuan instruksional umum (TIU)

2. Melakukan analisis instruksional

3. Mengidentifikasi perilaku dan karakteristik awal peserta didik

4. Menulis tujuan instruksional khusus

5. Menyusun alat penilaian hasil belajar

6. Mengembangkan strategi instruksional

7. Mengembangkan bahan instruksional

8. Menyusun desain dan melaksanakan evaluasi formatif

9. Revisi instruksional

Fokus penelitian adalah mengembangkan buku pengayaan pengetahuan yang layak untuk dapat digunakan sebagai sumber belajar pada kegiatan pengayaan dalam proses pembelajaran khususnya untuk KD 3.7 Kelas XI, yaitu Menerapkan prinsip fluida dinamik dalam teknologi.

Uji kelayakan dilakukan kepada ahli menggunakan instrumen berbentuk quesioner, mencakup aspek isi, sajian, bahasa, dan grafika yang dikembangkan dari instrumen penilaian buku pengayaan pengetahuan yang dikeluarkan oleh Pusat Kurikulun dan Perbukuan (Puskurbuk).

\section{HASIL DAN PEMBAHASAN}

\section{Studi pendahuluan}

Studi pendahuluan dilakukan di pusat kurikulum dan perbukuan (Puskurbuk), beberapa Sekolah Menengah Atas (SMA) di Jakarta, dua toko buku terkenal di Jakarta, dan juga toko buku online. Berdasarkan daftar judul buku pengayaan pengetahuan sebagai buku nonteks pelajaran yang memenuhi syarat kelayakan untuk digunakan sebagai sumber belajar pada jenjang pendidikan dasar dan menengah yang dikeluarkan oleh Puskurbuk tanggan 18 Juni 2012, tidak ada buku pengayaan pengetahuan yang bertemakan angin puting beliung. Akan tetapi, berdasarkan informasi yang diperoleh dari mesin pencarian ada dua buah buku yang bertemakan angin puting beliung. Yaitu "Buku Seri Penanggulangan Bencana: Angin Puting Beliung" terbitan Andi Publisher dan "Angin Puting Beliung" terbitan Erlangga Kids.

Berdasarkan analisis kebutuhan yang telah Penulis lakukan di beberapa toko buku besar di Jakarta, kedua judul buku tersebut sulit untuk ditemukan. Di toko buku kini, lebih banyak buku pengayaan pengetahuan dengan disain komik yang membahas cuaca atau iklim, dimana di dalamnya ada sub bab yang membahas mengenai bencana seperti angin topan atau tornado seperti pada buku "Why? Weather" terbitan elex media komputindo yang sudah di alihbahasakan dari terbitan Why Nalssi Korea dan "Up Science: Cuaca" terbitan Bhuana Ilmu Populer. Selain itu, ada pula buku "Atlas Bencana" dimana Angin Puting Beliung menjadi salah satu bencana yang dibahas dalam buku tersebut.

Sedangkan berdasarkan analisis kebutuhan di beberapa perpustakaan sekolah yang ada di Jakarta, $50 \%$ sekolah memiliki buku pengayaan dan 50\%-nya tidak memiliki buku pengayaan. Dari 50\% sekolah yang memiliki buku pengayaan, 12,5\%-nya terdata sangat jarang bahkan tidak pernah buku pengayaan yang ada dipinjam oleh siswa. Dari berbagai judul yang ditemukan di $50 \%$ sekolah tersebut, tidak ditemukan buku yang bertemakan angin puting beliung.

Buku pengayaan pengetahuan yang bertemakan atau di dalamnya terdapat sub bab materi mengenai angin puting beliung kini lebih banyak diperuntukan untuk siswa pendidikan dasar. Isi 
buku cenderung lebih fokus membahas cara menanggulangi bencana sehingga kurang membahas proses terjadinya puting beliung secara mandalam terutama dari konsep fisika.

\section{Buku Pengayaan Pengetahuan "Kajian Fisis Peristiwa Angin Puting Beliung}

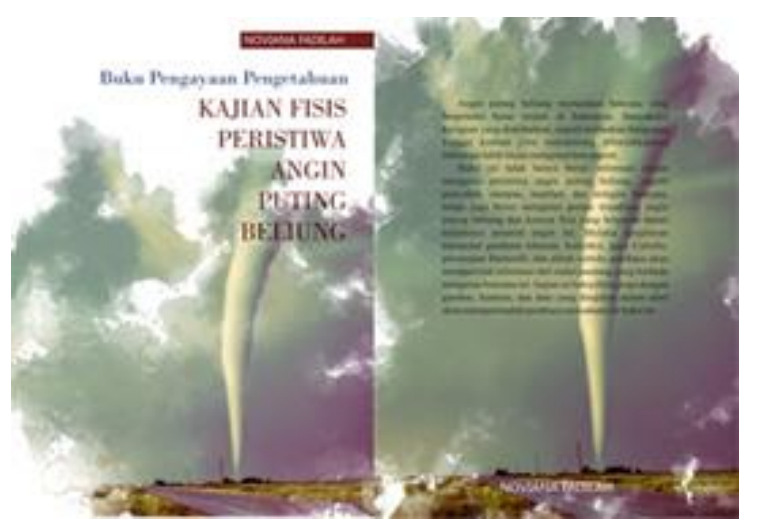

GAMBAR 1. Tampilan sampul buku pengayaan.

Buku pengayaan "Kajian Fisis Peristiwa Angin Puting Beliung" terdiri dari informasi umum dan juga kajian fisis angin puting beliung. Informasi umum terdapat pada Bab 3 berupa intensitas terjadinya bencana angin puting beliung, peristiwa-peristiwa angin puting beliung di Indonesia, data daerah rawan bencana, kerusakan yang dialami, dan dampak, serta pada Bab 5 yang berisi manfaat dalam meningkatkan nilai sosial masyarakat, dan mitigasi bencana. Sedangkan kajian fisis, terdiri dari besaran-besaran fisis angin, gaya pengendali angin yang terdapat pada Bab 2 serta isi keseluruhan Bab 4 yang membahas konveksi, gradien tekanan, kecepatan angin, gaya Coriolis, Persamaan Bernoulli, dan aliran vorteks. Pada Bab 5 subbab manfaat juga disajikan materi mengenai pemanfaatan konsep pusaran angin puting beliung sebagai pembangkit listrik menggunakan mesin AVE (Athmospheric Voretx Engine).

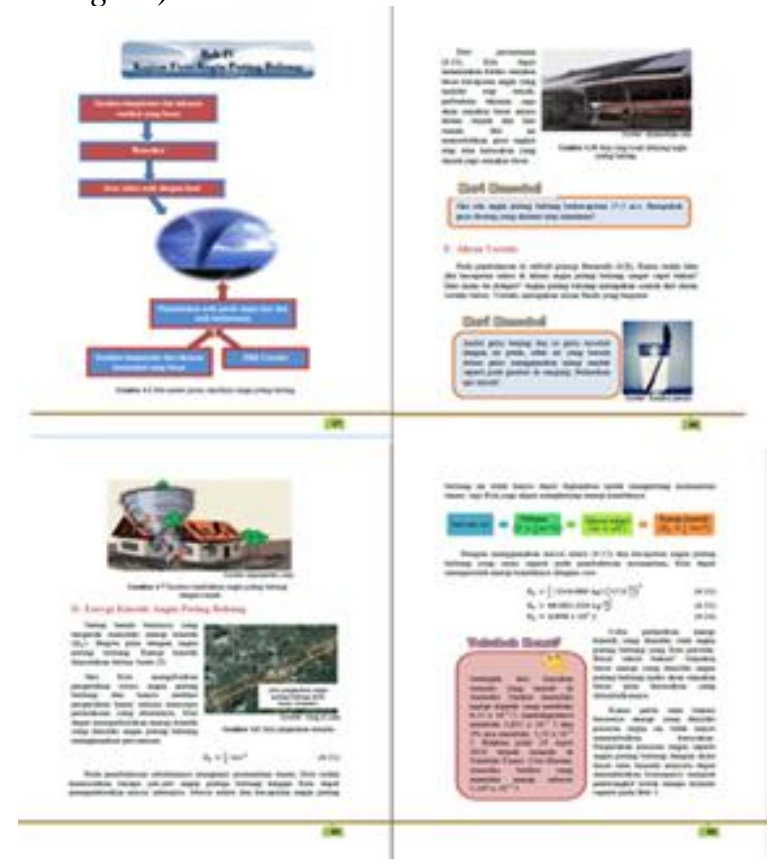

GAMBAR 2. Contoh isi Buku Pengayaan.

Untuk mempermudah pembaca memahami konsep, penyajian disertai beragam ilustrasi berupa gambar, bagan, peta, foto, sebagai pelengkap penjelasan. Terdapat pula data yang disajikan dalam tabel. Untuk info unik atau intisari dari suatu penjelasan tersaji dalam kotak "Tahukah Kamu?" Selain itu, bahasa yang digunakan juga lebih komunikatif. Untuk mengajak pembaca turut aktif, 
terdapat kotak "Mari mencoba!" untuk memotifasi siswa berpikir lebih jauh, mencari data, menganalisis suatu data, melakukan praktikum sederhana, dan memperkirakan suatu kejadian melalui perhitungan.

\section{Uji Keterbacaan}

Uji keterbacaan dilakukan untuk melihat apakah pembaca sasaran mengalami kesulitan dalam memahami isi buku, dan apakah buku yang dikembangkan dapat memotivasi pembaca untuk mengetahui isi buku. Uji keterbacaan dilakukan kepada delapan siswa SMA. Berdasarkan hasil uji keterbacaan kepada siswa SMA diperoleh rata-rata skor yang dijasikan pada TABEL 1.

TABEL 1. Hasil uji keterbacaan.

\begin{tabular}{lll}
\hline No. & Komponen & $\begin{array}{l}\text { Rata-rata } \\
\text { Skor }\end{array}$ \\
\hline 1. & Materi & $92,50 \%$ \\
2. & Penyajian & $88,50 \%$ \\
3. & Bahasa & $84,17 \%$ \\
4. & Grafika & $85,62 \%$ \\
\hline
\end{tabular}

Skor $87,5 \%$ menyatakan materi pada buku mudah dipahami dan $82,5 \%$ menyatakan penyajian materi dapat memotivasi untuk menggali informasi lebih lanjut, $80 \%$ menyatakan bahasa yang digunakan komunikatif, dan 92,5\% menyatakan gambar yang digunakan dapat mempermudah dalam memahami isi bacaan. Dari hasil keseluruhan uji keterbacaan, buku pengayaan pengetahuan "Kajian Fisis Peristiwa Angin Puting Beliung" memperoleh interpretasi keseluruhan sangat baik.

\section{Uji Kelayakan}

Buku pengayaan pengetahuan yang sudah dikembangkan diuji kelayakannya kepada empat orang penguji. Penilaian dan saran dari penguji kelayakan akan menjadi bahan pertimbangan untuk merevisi dan memperbaiki buku "Kajian Fisis Peristiwa Angin Puting Beliung" sehingga produk yang dihasilkan memiliki kualitas yang lebih baik lagi. Adapun hasil skor untuk masing-masing sub komponen oleh para penguji disajikan pada TABEL 2.

TABEL 2. Sub total skor komponen.

\begin{tabular}{clcccc}
\hline & & \multicolumn{4}{c}{ Skor Uji Kelayakan } \\
\cline { 3 - 6 } No. Komponen & $\begin{array}{c}\text { Penguji } \\
\text { Kelayakan }\end{array}$ & $\begin{array}{c}\text { Penguji } \\
\text { Kelayakan }\end{array}$ & $\begin{array}{c}\text { Penguji } \\
\text { Kelayakan }\end{array}$ & $\begin{array}{c}\text { Penguji } \\
\text { Kelayakan }\end{array}$ \\
\hline 1. & Materi & $\mathbf{1}$ & $\mathbf{2}$ & $\mathbf{3}$ & $\mathbf{4}$ \\
2. & Penyajian & 75,90 & 85,00 & 88,50 & 85,80 \\
3. & Bahasa & 73,02 & 75,67 & 77,37 & 75,75 \\
4. & Grafika & 80,67 & 75,00 & 80,00 & 77,00 \\
\hline
\end{tabular}

Dengan menggunakan perhitungan berdasarkan aturan penilaian buku pengayaan pengetahuan dari Puskurbuk, total skor akhir diperoleh menggunakan rumusan sebagai berikut.

Total skor akhir $=$ Sub total skor komponen $($ materi $\times 0,4)+($ penyajian $\times 0,3)+($ bahasa $\times 0,2)+$ (grafika $\times 0,1$ )

Sehingga diperoleh total skor akhir untuk masing-masing penguji seperti yang disajikan pada TABEL 3. 
TABEL 3. Total skor skhir.

\begin{tabular}{cc}
\hline Penguji Kelayakan & Total Skor Akhir \\
\hline 1 & 80,13 \\
2 & 79,23 \\
3 & 83,58 \\
4 & 81,28 \\
\hline Rerata Skor Akhir & 80,98 \\
\hline
\end{tabular}

Berdasarkan syarat kelayakan buku pengayaan pengetahuan, yaitu (1) butir pada komponen materi harus berskor $\geq 6$, (2) butir pada komponen penyajian, bahasa, dan grafika harus berskor $\geq 3$, dan (3) total skor akhir dari seluruh komponen minimal 55. Buku pengayaan pengetahuan"Kajian Fisis Peristiwa Angin Puting Beliung" memenuhi ketiga syarat kelayakan di atas. Dimana komponen materi memiliki skor terendah 6 dan tertinggi 10, komponen penyajian memiliki skor terendah 6 dan tertinggi 9, komponen bahasa memiliki skor terendah 7 dan tertinggi 8 , skor grafika memiliki skor terendah 7 dan tertinggi 10. Total skor akhir untuk masing-masing penguji juga lebih besar dari 55 .

Predikat kelayakan buku menurut Puskurbuk dinyatakan pada TABEL 4.

TABEL 4. Skor penentu kelayakan buku.

\begin{tabular}{|c|c|}
\hline $\begin{array}{l}\text { Total Skor } \\
\text { Akhir }\end{array}$ & Makna \\
\hline Skor $\geq 85$ & $\begin{array}{l}\text { Layak dengan predikat } \\
\text { Sangat Baik }\end{array}$ \\
\hline $55 \leq$ skor $<85$ & $\begin{array}{l}\text { Layak dengan predikat } \\
\text { Baik }\end{array}$ \\
\hline skor $<55$ & Tidak Layak (TL) \\
\hline
\end{tabular}

Berdasarkan TABEL 4, dengan rerata skor akhir 81,05, buku pengayaan pengetahuan"Kajian Fisis Peristiwa Angin Puting Beliung” dinyakan layak dengan predikat baik.

\section{SIMPULAN}

Berdasar uji kelayakan, buku pengayaan pengetahuan berjudul "Penerapan Konsep Fisika dalam Peristiwa Angin Puting Beliung" layak diberi predikat baik sebagai buku pengayaan pengetahuan. Dari hasil uji keterbacaan, diperoleh interpretasi keseluruhan sangat baik.

\section{UCAPAN TERIMAKASIH}

Terima kasih disampaikan kepada Bapak/Ibu validator yang telah memberikan saran perbaikan dan kepada panitia seminar nasional fisika tahun 2017 yang telah memberi kesempatan kepada kami untuk mempublikasikan artikel ini.

\section{REFERENSI}

Chapter 9: The temperature gradien, http://www.bergbahnen-werfenweng.com. n.d.

Dick \& Carey 2009, The Systematic Design of Instruction, Pearson, USA.

E, Nurjani 2013, 'Kajian Bencana Angin Ribut di Indonesia Periode 1990-2011', Geomedia Volume 11 No 2.

Gomduri 2015, Up Science: Cuaca, PT Bhuana Ilmu Ppopuler, Jakarta.

Pedoman Penilaian Buku Nonteks Pelajaran tahun 2014, 2014, Kementrian Pendidikan Nasional Pusat Kurikulum dan Perbukuan.

Siswanto 2012, 'Identifying Precursor Condition for "Puting Beliung", Widyariset Vol 15 No. 3. 
Sitepu 2012, Penulisan Buku Teks Pelajara, PT Remaja Rosdakarya, Bandung.

Sudibyakto \& Daryono 2008, Waspadai Puting Beliung. UGM, Yogyakarta

Supriyono, Primus 2015, Seri Pendidikan Pengurangan Risiko Bencana Angin Puting Beliung, Penerbit Andi, Yogyakarta. 
